\title{
Production and characterization of alginate microparticles obtained by ionic gelation and electrostatic adsorption of concentrated soy protein
}

\section{Gabriela Barros Silverio ${ }^{1}$ Lyssa Setsuko Sakanaka ${ }^{1}$ Izabela Dutra Alvim $^{2}$ Marianne Ayumi Shirai ${ }^{1}$ Carlos Raimundo Ferreira Grosso ${ }^{*}$}

${ }^{1}$ Programa de Pós-graduação em Tecnologia de Alimentos, Universidade Tecnológica Federal do Paraná (UTFPR), 86036-370, Londrina, PR, Brasil. E-mail: carlosgrosso@utfpr.edu.br. "Corresponding author.

${ }^{2}$ Centro de Tecnologia de Cereias e Chocolates, Instituto de Tecnologia de Alimentos (ITAL), Campinas, PR, Brasil.

ABSTRACT: Microencapsulation is used for protection and release of bioactive compounds. Combination of encapsulation methods allows the production of matrices with better technological properties compared to the application of one of the methods alone. Use of ionic gelation produces porous microparticles, and coating it with a protein, by electrostatic interaction, may contribute to a better protection of the active compound. The objective of the research was to produce alginate microparticles (AG) through ionic gelation and to coat them with soluble protein from soy protein concentrate. Two factors were studied, calcium concentration during ionic gelation $(0.8,1.6$ and $2.4 \% \mathrm{w} / \mathrm{w})$ and $\mathrm{pH}(3.5$ and 7.0$)$ of the protein solution for electrostatic interaction. Zeta potential (ZP) of biopolymers and microparticles were determined. Microparticles were characterized according to its morphology, average size and size distribution, as

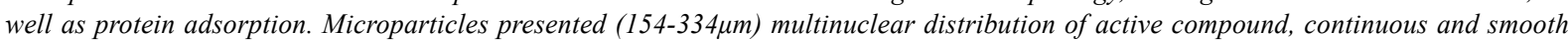
surface, with a great standard deviation considering average size. The calcium concentration did not influence the protein adsorption on microparticles. The $\mathrm{pH}$ used in protein adsorption showed significant effect, with higher adsorption occurring at pH 3.5 (6.5 to $6.7 \%$ $w / w$, dry basis, $d b$, of adsorbed protein) compared to $\mathrm{pH} 7.0(<2.0 \% \mathrm{w} / \mathrm{w}, \mathrm{db}$, of adsorbed protein) indicating that electrostatic interaction was determinant for the protein coating. At this situation, ionic gelation microparticles and proteins presented ZP with opposite charges ( $\mathrm{pH}>\mathrm{pKa} A G<$ Isoelectric point, $I P$ ).

Key words: Microencapsulation, ionic gelation, electrostatic interaction, alginate, soy protein.

Produção e caracterização de micropartículas de alginato obtidas por gelificação iônica e adsorção eletrostática de concentrado proteico de soja

RESUMO: A microencapsulação é utilizada para a proteção de compostos bioativos e controle de sua liberação. A combinação de métodos de encapsulação permite a obtenção de matrizes com melhores propriedades tecnológicas em relação às técnicas utilizadas individualmente. Na gelificação iônica são produzidas micropartículas porosas, e o recobrimento por interação eletrostática com uma proteína permite a obtenção de micropartículas mais protetivas. O objetivo do trabalho foi produzir micropartículas de alginato (AG) através da gelificação iônica e recobri-las com proteinas solúveis de concentrado proteico de soja. Dois fatores foram estudados, o teor de cálcio utilizado na gelificação iônica $(0,8,1,6$ e 2,4\% $\mathrm{m} / \mathrm{m})$ e o $\mathrm{pH}(3,5$ e 7,0$)$ para o recobrimento eletrostático com uma camada proteica. Os potenciais zeta (PZ) dos biopolímeros e das micropartículas foram determinados. As micropartículas foram caracterizadas quanto a morfologia, tamanho médio e sua distribuição e quanto ao teor de proteina adsorvida nas situações estudadas. As micropartículas obtidas apresentaram-se (154-334 4 ) com recheio distribuido de forma multinuclear, com superfície continua e visualmente lisas, porém com variação grande no tamanho médio. A variação do teor de cálcio não foi significativa na adsorção proteica. O pH utilizado na adsorção proteica foi significativo, com adsorções muito maiores em $\mathrm{pH}$ 3,5 (6,5 - 6,7\% m/m de proteina adsorvida, base seca) comparado ao pH 7,0 (<2,0\% $\mathrm{m} / \mathrm{m}$ de adsorção proteica, base seca), indicando que a interação eletrostática foi determinante no recobrimento proteico. Nesta situação, micropartículas AG e a proteína apresentam PZ com cargas opostas ( $\mathrm{H}>\mathrm{pKa} A \mathrm{~A}<$ ponto isoeletrico, PI).

Palavras-chave: Microencapsulação, gelificação iônica, interação eletrostática, alginato, proteína de soja.

\section{INTRODUCTION}

Microencapsulation is a coating process that, allows controlled release of the encapsulated materials at a desired location and time after applying a specific stimulus. These materials have applications in pharmaceutical, food, agricultural, livestock industries, and several other such fields (JAFARI, et al., 2008).
In addition to controlling the release of the encapsulated materials, encapsulation can also protect materials from the variations in $\mathrm{pH}$, light, oxygen, conditions of passage through the gastrointestinal tract, and evaporation of encapsulated active material, thereby increasing their shelf-life. Furthermore, this process allows the masking of undesirable flavors and odors and facilitates the handling of active materials 
(DESAI \& PARK, 2005). Different compounds are often encapsulated, including (but not limited to) antioxidants, bioactive compounds, essential fatty acids, enzymes, and microorganisms (CHAMPAGNE \& FUSTIER, 2007).

Ionic gelation occurs through the interaction of an anionic polymer solution with ions such as calcium (BUREY et al., 2008). Mechanism of ionic gelation is described using an egg box model in which the carboxylic acid groups in polysaccharides, especially sequences of guluronic acid $(\mathrm{G})$ in the case of alginate, interact with calcium ions at $\mathrm{pH}$ levels that exceed the pKa of the polysaccharide (MESTDAGH \& AXELOS, 1998). Ionic gelation is a simple, cheap, and fast method that uses non-toxic polysaccharides, requires mild temperatures, and does not require organic solvents (SCHOUBBEN et al., 2010).

The gel matrix that is obtained by ionic gelation is characterized by low mechanical resistance and high porosity and some strategies, such as the coating of microparticles with a polyelectrolyte having an opposite charge to that possessed by the gel, have been proposed to improve this functionality through electrostatic interactions (WANDREY et al., 2010). Generally, proteins and polysaccharides are used as positive and negative polyelectrolytes, respectively (KRASAEKOOPT et al., 2003, GOUIN, 2004, FARRIS et al., 2009).

Alginate is a linear hydrocolloid that is obtained from brown marine algae such as Laminariadigitata and Macrocystispyrifera. This biomaterial contains $\beta$-D-mannuronic acid (M) and $\alpha$-L-guluronic acid $(\mathrm{G})$ in the form of sodium salts, which is bound together by $\alpha 1-4$ glycosidicbonds in homopolymer blocks (MM and GG) that are interspersed by heteropolymeric blocks (MG) in the polysaccharide chain (DRAGET et al., 2006).

Soybean (Glycine $\max (\mathrm{L}$.) Merrill) has an average protein and oil content of $40 \%$ and $20 \%$, respectively (EMBRAPA, 2004). Soy proteins are classified as globular and are insoluble in aqueous media at their isoelectric point (IP: 4.5). However, these proteins are soluble in water or in dilute saline solutions at $\mathrm{pH}$ values that are lower than or higher than their IP values (SGARBIERI, 1996). The predominant soybean proteins are $\beta$-conglycinins and glycinines, which exhibit sedimentation coefficients of $7 \mathrm{~S}$ and $11 \mathrm{~S}$ for proteins of molar masses 180 210 and $350 \mathrm{kDa}$, respectively (VELASQUEZ \& BHATHENA, 2007).

The majority of the literature related to the electrostatic adsorption of proteins onto microparticles focussed on globular proteins specially using whey proteins ( $\beta$-lactoglobulin $\sim 65 \%$ of whey total proteins, $18.4 \mathrm{KDa}$ ) according to DOHERTHY et al. (2011). The $7 \mathrm{~S}$ and $11 \mathrm{~S}$ protein fractions of CPS presents large molar mass compared to $\beta$-lactoglobulin and can produce different effects on the porosity of microparticles obtained by ionic gelation after adsorption of protein on the microparticles (WANDREY et al., 2010). The identification of new plant protein materials besides animal globular protein as whey protein, that can be applied to produce an adsorbed layer on microparticles could expand their functionalities and applications. Hence, the objective of the present study is to develop microparticles from sodium alginate using ionic gelation and to coat them with globular soluble proteins that are extracted from CPS using electrostatic interactions. We further evaluate the adsorption of these soybean proteins on the microparticles in addition to comparing the physico-chemical and morphological properties of alginate microparticles with and without adsorbed proteins. Although, the core material is very important, in the present work one oily emulsified material was used (oleoresin: sunflower oil) as a model core material with the purpose to confer color to the microparticles during morphological evaluation and this oily material can be useful especially to carrier hydrophobic active compounds or hydrophilic compounds and emulsifiers; however, the protection of the core model material and its release were not the aim of this research.

\section{MATERIALS AND METHODS}

The materials used in this study included a high molar mass sodium alginate with a high content of guluronic acid (lot GA 1006403, PROTANAL RF 6650 and a viscosity of between 400 and $600 \mathrm{mPas}$, $1 \%, 20^{\circ} \mathrm{C}$; FMC Biopolymer, Campinas-SP, Brazil); a soy protein concentrate (Bremil, Arroio do MeioRS, Brazil); paprika oleoresin (Citromax, Guarulhos, São Paulo, Brazil); Coomassie Brilliant Blue (Sigma Aldrich, St. Louis MO, USA); commercial sunflower oil; and calcium chloride (lot 205338, Synth, DiademaSP, Brazil). Reagents provided by Alphatec, São Jose dos Pinhais, PR, Brazil included 0.1N hydrochloric acid (lot 20905G), 50\% sodium hydroxide (lot 22816), concentrate sulfuric acid, and sodium citrate (lot 23739). Solutions, emulsions, and microparticles were prepared using distilled and deionized water. All the reagents that were used were of analytical grade.

Physico-chemical characterization of biopolymers

The CPS and alginate were characterized with respect to the moisture, ash, and protein 
contents (AOAC, 2006). The moisture content was determined using an oven at $105^{\circ} \mathrm{C}$ until constant weight was observed via gravimetric analysis. The ash content was determined by incinerating the samples in a muffle for $5 \mathrm{~h}$. The amount of protein was determined using the Kjeldahl method with a conversion factor of 6.25 .

\section{Production of soluble proteins from soy protein concentrate}

Solutions were prepared with CPS at a concentration of $2.5 \%(\mathrm{w} / \mathrm{w})$ and were stirred at $40^{\circ} \mathrm{C}$ (MAGHS7S32, IKA, Works do Brasil, RJ, RJ, Brazil). The $\mathrm{pH}$ was adjusted to 11 with $0.1 \mathrm{~N} \mathrm{NaOH}$ while agitating the system for $30 \mathrm{~min}$. Further, the $\mathrm{pH}$ values of the solution were adjusted to 3.5 and 7.0 with $0.1 \mathrm{~N}$ hydrochloric acid or $0.5 \mathrm{~N}$ sodium hydroxide, respectively. Both the solutions were stirred at room temperature for $30 \mathrm{~min}$ and were then refrigerated for $24 \mathrm{~h}$ to allow phase separation. Supernatant that contained soluble proteins was removed for use in the protein adsorption experiments. The total amount of protein in the supernatant was determined based on the Kjeldahl method (AOAC, 2006).

\section{Production of alginate microparticles using ionic gelation \\ A $2 \% \mathrm{w} / \mathrm{w}$ alginate solution was emulsified} with $2 \% \mathrm{w} / \mathrm{w}$ oleoresin (1:9 oleoresin/sunflower oil) over a period of $3 \mathrm{~min}$ at $14,000 \mathrm{rpm}$ using a Turrax mixer (T-18, IKA Works do Brasil, RJ, Brazil), resulting in yellow-red colored emulsion, which was further atomized over a $0.8,1.6$, or $2.4 \% \mathrm{w} / \mathrm{w}$ calcium chloride solution, with continuous agitation, using a double fluid atomizer (LAB MAQ, RibeirãoPreto, SP, Brazil) under the following conditions to produce spherical microparticles: $\varnothing 0.7 \mathrm{~mm}$, a $12-\mathrm{cm}$ distance between the double fluid atomizer and the calcium chloride solution, an air pressure of $15 \mathrm{kgf} / \mathrm{cm}^{2}$, and an atomization speed of $160 \mathrm{~mL} / \mathrm{h}$, provided by a peristaltic pump (MUKAI-CORÊA, 2004). After production, microparticles were agitated in a calcium chloride solution for $30 \mathrm{~min}$ to complete the ionic gelation process. Microparticles were further washed with water and separated using a steel sieve (Ø $53 \mu \mathrm{m}$; Bertel, Caieiras-SP, Brazil). Two independent repetitions were performed at varying calcium concentrations $(0.8,1.6$, and $2.4 \% \mathrm{w} / \mathrm{v})$.

Electrostatic adsorption of proteins on the alginate microparticles

The moist alginate microparticles $(50 \mathrm{~g})$ were transferred to into soluble protein solutions at
pH 3.5 and $7.0(200 \mathrm{~mL})$ and agitated for $30 \mathrm{~min}$ at room temperature. The recovered microparticles $(\varnothing$ $53 \mu \mathrm{m}$ steel sieve) were washed with water $(\mathrm{pH} 3.5$ or 7.0) to remove non-adsorbed proteins. Adsorption procedure was repeated thrice at each $\mathrm{pH}$.

\section{Composition of the microparticles}

The moisture, ash, and protein contents of the microparticles were measured as per the characterization of biopolymers, which has been described above.

\section{Quantification of the microparticles' calcium content}

The calcium content of microparticles obtained by ionic gelation was determined using an atomic absorption spectrophotometer (Analytic Jena AG-NOVAA300, Jena, Alemanha, flame AAS mode, Central Analitica, IQ, Unicamp). Samples of the same independent treatments were mixed and microparticles were dissolved in 3\% w/w sodium citrate before analysis (SRIAMORNSAK e KENNEDY, 2008), and a standard solution of calcium $(1000 \mu \mathrm{g} / \mathrm{mL}, \mathrm{SCP}$ Science, lot S120221015, Quebec, Canada) was used for absolute quantification. Preliminary evaluation depicted that sodium citrate did not interfere in the calcium content determination. The measurements were performed in triplicate.

Zeta potential of the solutions and alginate microparticles with or without covered protein

Zeta potentials (ZPs) of the diluted solutions $(0.2 \% \mathrm{w} / \mathrm{w})$ of soluble proteins at $\mathrm{pH} 3.5$ and 7.0 , of $2 \%$ alginate solutions/emulsions, and of microparticles with and without adsorbed proteins were determined using a Zetasizer Nano-Z (Malvern Instruments, Worcestershire, U.K.). Samples of the same independent treatment were mixed before performing ZP determinations, the diluted samples containing the microparticles were homogenized at 15,000rpm/5min using a Turrax mixer (T-18, IKA, Works do Brasil, RJ, RJ, Brazil) in accordance with DOHERTHY et al. (2011). The ZP determinations were repeated five times. Preliminary evaluations of the polysaccharide solutions or emulsions did not exhibit any differences in the zeta values.

Average size, size distribution, and polydispersity index

The average size $\left(\mathrm{D}_{0.5}\right)$ and size distribution of microparticles without or with adsorbed proteins were conducted using light scattering (LV950-V2, Horiba, Kyoto, Japan) in water at $\mathrm{pH} 3.5$ or 7.0 as dispersant. Polydispersity index (span index) was calculated as $\left(\mathrm{D}_{0.9}-\mathrm{D}_{0.1}\right) / \mathrm{D}_{0.5}$, where $\mathrm{D}_{0.9}$ was 
the microparticle size below which $90 \%$ of the distribution existed, $\mathrm{D}_{0.5}$ was the average diameter, and $\mathrm{D}_{0.1}$ was the microparticle diameter below which $10 \%$ of the distribution existed. The $\mathrm{D}_{0.5}$ corresponds to averages of two independent repetions for the production of microparticles at each calcium level and three independent repetitions for adsorption of protein at each $\mathrm{pH}$ value.The means size of each sample was measured six times. The same procedure was used to calculate the polydispersity index.

\section{Morphology of the moist microparticles}

The morphology of the moist microparticles with or without the adsorbed proteins was observed using optical microscopy (BX4, Olympus, Tokyo, Japan) using a 10× objective lens. Images were acquired using a digital camera (Q - Color 3, Olympus, Tokyo, Japan). Two light sources were used, which included a conventional transmitted light source and an incident external source produced using an optical fiber (model LGPS, light optical fiber, Olympus 9095, Tokyo, Japan) that was directly focused onto the sample without contact with manually adjusted height of 1 to $3 \mathrm{~cm}$, to allow the best focus. The latter strategy allows for a threedimensional depth discrimination in images, which improves the morphological evaluations.

\section{Morphological evaluation of protein adsorption using Coomassie blue}

Microparticles produced using 0.8, 1.6, and $2.4 \% \mathrm{w} / \mathrm{w}$ calcium solution, without or with adsorbed protein at $\mathrm{pH} 3.5$ and 7.0, were stained for protein using Coomassie Brilliant Blue, according to LAEMMLI (1970). Imaging of stained and after discolored microparticles was performed using the operational conditions described above.

\section{Statistical analyses}

Results were evaluated by analysis of variance (ANOVA) and the Tukey Test, with a 5\% significance level, using the SAS program (Cary, NC, USA). With the exception of the morphological evaluations, all the determinations were performed using $\mathrm{n} \geq 3$ measurements.

\section{RESULTS AND DISCUSSION}

\section{Physico-chemical characterization of biopolymers}

The CPS comprised $70.5 \pm 0.1 \%$ protein, $5.7 \pm 0.5 \%$ moisture, and $3.6 \pm 0.1 \%$ ash. The alginate contained $10.8 \pm 0.2 \%$ moisture and $28.0 \pm 2.2 \%$ ash. The CPS protein content complied with Anvisa
RDC 268, de 23/09/2005, which stipulated that CPS should contain at least $68 \%$ protein (BRASIL, 2005). The high ash content can be justified by the usage of sodium alginate that was produced from alginic acid (KELCO, 1987).

\section{Production of soluble proteins from concentrated soy protein}

Protein extraction from CPS was achieved after preliminary studies involving filtration, centrifugation, and decantation exhibited that decantation alone was sufficient for separation of soluble protein; therefore, decantation was used to extract proteins at $\mathrm{pH} 3.5$ and 7.0.

The CPS solution was initially adjusted to $\mathrm{pH}$ 11 to maximize the protein solubility and the extraction based on a previously determined $\mathrm{pH}$-dependent solubility curve for soy proteins (SGARBIERI, 1996). Samples of this extract were further adjusted to either $\mathrm{pH} 3.5$ or 7.0 before protein adsorption on alginate particles; $51.0 \pm 0.9 \%$ and $61.8 \pm 1.8 \%$ of the proteins were soluble at $\mathrm{pH} 3.5$ and 7.0, respectively.

\section{Quantification of calcium in microparticles}

The calcium content was highest $(162.0 \mathrm{mg} / \mathrm{L})$ in microparticles that were processed at the highest concentration, which was followed by the microparticles processed in $1.6 \%$ and $0.8 \%$ solutions (142.7 and $137.3 \mathrm{mg} / \mathrm{L}$, respectively). These results indicated that an increase in the calcium chloride concentration increased the calcium content of microparticles. Microparticles calcium content did not differ significantly between the samples prepared in $0.8 \%$ and $1.6 \% \mathrm{w} / \mathrm{w}$ calcium solutions; however, calcium levels differed between the samples prepared in $0.8 \%$ and $2.4 \%$ as well as $1.6 \%$ and $2.4 \% \mathrm{w} / \mathrm{w}$ calcium. According to PATHAK et al. (2010), the higher the concentration of the calcium chloride solution, the greater the gel surface packed arrangment, reducing the porosity and the intrusion volume of the microparticle.

\section{ZPS of solutions and alginate microparticles with or without covered protein}

The zeta potential of the alginate solution was negative $(-79.6 \mathrm{mV}, \mathrm{pH} 6.7)$ and similar to that observed in previous studies $(-68 \mathrm{mV}$ at $\mathrm{pH} 7.0$, ZHANG et al., 2016). This negative zeta value is attributed to the dissociated carboxyl groups of guluronic and mannuronic acids that are present in the alginate molecule (pKa 3.5, BAJPAI \& TANKHIWALE, 2008). At pH 3.5 and 7.0, the CPS soluble protein extract had ZPs of 27.6 and $-13.1 \mathrm{mV}$, 
respectively, which was also close to the previously reported data (SANTIAGO et al., 2008).

The ZPs of alginate microparticles were also measured at three different calcium concentrations $(0.8,1.6$, and $2.4 \% \mathrm{w} / \mathrm{w})$ to evaluate whether this factor is important for determining its influence on the microparticle zeta potentials, and the subsequent amount of protein adsorbed on the microparticles at $\mathrm{pH} 3.5$ and 7.0 (Table 1).

Microparticles without adsorbed proteins exhibited ZPs of $-18.6 \pm 0.3 \mathrm{mV},-25.0 \pm 2.2 \mathrm{mV}$, and $-21.0 \pm 1.9 \mathrm{mV}$ at $\sim \mathrm{pH} 6$ in $0.8,1.6$, and $2.4 \% \mathrm{w} / \mathrm{w}$ calcium solutions, respectively, with significant differences between 0.8 and $1.6 \%$ of calcium (Table 1). YEUNG et al. (2016) obtained ZPs varying from -4.2 to $-9.4 \mathrm{mV}$ for alginate microparticles encapsulating $B$. infantis and from -2.6 to $-4.4 \mathrm{mV}$ for microparticles containing B. Longum. ZEEB et al. (2015) encapsulated one triglyceride $\left(\mathrm{MIGLYOL}^{\circledR}\right.$ 812) using alginate microparticles and a non-ionic surfactant (Tween 60) to obtain zeta values of approximately $-2.5,-10,-18$, and -37 at $\mathrm{pH} 2,5,6$, and 11, respectively. Our comparisons between the ZPs of uncoated microparticles in varying concentrations of calcium (Table 1) demonstrated a substantial decrease in particle charge compared to the charge of polysaccharide solution, which indicated the ionic associations between the alginate carboxyl groups and calcium ions that have also been previously reported (MAESTRELLI et al., 2008).

Although, microparticle without protein ZPs were much lower than those of the alginate solution (Table 1), there was no proportional change in the ZPs with an increase in the calcium concentrations. It is possible that the calcium amount used was too small to produce a significant proportional change in ZP of microparticles without the presence of adsorbed protein. In general, majority of the literature examples have used calcium ion concentrations between 1 and $5 \%$ and alginate concentrations between 1 and $3 \%$.
However, for the production of microparticles by ionic gelation, much higher concentrations have been used such as between 0.5 and $1.0 \%$ alginate and $10 \% \mathrm{Ca}^{2+}$ (ZHANG et al., 2016).

At pH 7.0 (Table 1), the results of $\mathrm{ZP}$ obtained for microparticles with protein were negative as obtained for samples without protein coating, as a consequence of negative charge presented by soy protein at $\mathrm{pH}$ above the IP. Although, all the microparticles coated with protein at $\mathrm{pH} 7.0$ exhibited negative $\mathrm{ZP}$ values and significant difference between $0.8 ; 1.6$ and $2.4 \%$ of calcium, a proportional variation in the ZP values was not observed with increasing concentrations of calcium ions.

Microparticles coated with protein at $\mathrm{pH} 3.5$ (Table 1) had the lowest ZPs: $7.3 \pm 0.2 \mathrm{mV},-9.6 \pm 0.7 \mathrm{mV}$, and $-17.4 \pm 1.2 \mathrm{mV}$ for the $2.4 \%, 0.8 \%$, and $1.6 \%$ $\mathrm{Ca}^{2+}$ solutions, respectively, showing significant differences. Only at the highest amount of calcium the ZP of microparticles was positive. At this $\mathrm{pH}$ value we expected to observe positive $\mathrm{ZP}$ values after coating $(\mathrm{pH}<\mathrm{IP})$. The negative values at lower calcium concentrations could indicate that the concentration of protein that was used was too low to allow sufficient protein adsorption to overcome the remaining negative charges on the alginate microparticles.

Determination of the ZPs for large microparticles can present problems while using electrophoretic measurements because the microparticles have to be in a colloidal state to ensure mobility in the electric field during measurement. According to the manufacturer of the instrument that is used in this study (Zetasizer Nano-Z, Malvern Instruments), the recommended microparticle size limit is $10 \mu \mathrm{m}$, which is much smaller than that of the microparticles that are obtained in the present study. Despite this restriction, previous studies have performed measurements for microparticle sizes having a same or greater order of magnitude using

Table 1 - Zeta potencial of microparticles produced at different concentrations of calcium in solution.

\begin{tabular}{|c|c|c|c|}
\hline $\mathrm{CaCl}_{2}(\%)$ & $\begin{array}{l}\text { Microparticles produced by } \\
\text { ionic gelation without protein }\end{array}$ & $\begin{array}{l}\text { Microparticles covered with } \\
\text { protein at } \mathrm{pH} 3.5\end{array}$ & $\begin{array}{l}\text { Microparticles covered with } \\
\text { protein at } \mathrm{pH} 7.0\end{array}$ \\
\hline 0.8 & $-18.6 \pm 0.3^{\mathrm{aB}}$ & $-9.6 \pm 0.7^{\mathrm{bA}}$ & $-25.3 \pm 0.6^{\mathrm{bC}}$ \\
\hline 1.6 & $-25.0 \pm 2.2^{\mathrm{bB}}$ & $-17.4 \pm 1.2^{\mathrm{cA}}$ & $-29.4 \pm 1.8^{\mathrm{cA}}$ \\
\hline 2.4 & $-21.0 \pm 1.9^{\mathrm{abB}}$ & $7.3 \pm 0.2^{\mathrm{aA}}$ & $-19.1 \pm 1.2^{\mathrm{aB}}$ \\
\hline
\end{tabular}

Means followed by the same letter, lower cases in the column and capital letters in the same row do not differ statistically from each other by the Tukey test at $5 \%$ significance. 
this instrument without performing any additional treatments (ZHANG et al., 2016; ZEEB et al., 2015). As an alternative, we adopted the strategy used by DOHERTY et al. (2011), following the reduction of particle size after protein adsorption and before ZP determination. Although, deviations in measurements that are obtained for microparticles with or without adsorbed protein are observed to be low, it is possible that the conditions used to disintegrate the microparticles did not allow a complete homogenization of the sample. Hence, this method requires further optimization for future investigations.

\section{Composition of microparticles covered with protein}

The amount of protein adsorbed onto particles at $\mathrm{pH} 3.5$ and 7.0, moisture content, and ash content are presented in table 2 . The particle moisture contents were similar for all treatments, ranging from 95 to $96 \%$, without any significant differences for solutions of the same $\mathrm{pH}$. The high microparticle water content can be justified by the high water retention capacity of the alginate polysaccharide, which is structured in three-dimensional hydrophilic networks (LIU et al., 2007). Particles had low ash content, ranging from 0.26 to $0.49 \%$ at $\mathrm{pH} 7.0$ and from 0.38 to $0.41 \%$ at $\mathrm{pH} 3.5$.

The protein adsorption at different $\mathrm{pH}$ 3.5 or 7.0 , relative to the amount of calcium in microparticles $(0.8 ; 1.6$ and $2.4 \%$, Table 2$)$, is practically constant and independent of the calcium concentration in the solution, without significant differences. However, the amount of calcium present in the microparticles increased as the amount of calcium in solution increased during the production of the microparticles.
Protein adsorption is a phenomenon that involves the chemical properties of the protein molecule and its different surface forces, including van der Waals forces, hydrogen bonds, and, in particular, electrostatic and hydrophobic interactions ( $\mathrm{ROACH}$ et al., 2005). CPS protein adsorption to alginate microparticles was investigated as a function of the solution $\mathrm{pH}$ (Table 2), and it was observed that protein content at $\mathrm{pH} 3.5$ was approximately 3.5 times higher than that obtained at $\mathrm{pH} 7.0$, with values varying from 6.5 to $6.7 \%$ of adsorbed protein on microparticles, $\mathrm{db}$. These results demonstrated that the $\mathrm{pH}$ of the medium at $\mathrm{pH} 3.5$, at which the protein and alginate microparticles are positively and negatively charged, respectively, favors the protein adsorption. Our results indicated that electrostatic interactions are the most important factors for determining the total adsorbed protein. However, higher protein adsorption values have been obtained for globular animal proteins, including egg albumin, ovalbumin/whey protein (1:1) and whey protein, which resulted in $\sim 15 \%, \sim 16 \%$, and $\sim 20 \%$ of adsorption (w/w of microparticles, $\mathrm{db}$ ) using more concentrated protein solutions (TELLO, 2015).

Results presented in table 2 exhibit that, even at $\mathrm{pH} 7$, microparticles had approximately $2 \%$ of protein adsorption by weight when both proteins and microparticles exhibited a net negative charge. MOLINA-ORTIZ al. (2004) studied the interactions between soy protein and carrageenan and observed that complexes between proteins and polysaccharide were formed at both high and low $\mathrm{pH}$ values. According to the authors, hydrophobic interactions are the dominant interactions in complexes at high $\mathrm{pH}$, whereas electrostatic interactions dominate at low $\mathrm{pH}$. Associations at high $\mathrm{pH}$ values, where both

Table 2 - Content of moisture, protein and ash in the microparticles produced with different calcium concentration in solution and at different $\mathrm{pH}$ values.

\begin{tabular}{ccccc}
\hline $\mathrm{pH}$ & $\mathrm{CaCl}_{2}(\%)$ & protein $(\%)$ & moisture $(\%)$ & $\operatorname{ash}(\%)$ \\
\hline 7.0 & 0.8 & $1.9 \pm 0.2^{\mathrm{a}^{*}}$ & $96.0 \pm 0.9^{\mathrm{a}}$ & $0.49 \pm 0.00^{\mathrm{b}}$ \\
7.0 & 1.6 & $1.8 \pm 0.0^{\mathrm{a}}$ & $96.0 \pm 0.3^{\mathrm{a}}$ & $0.29 \pm 0.00^{\mathrm{a}}$ \\
7.0 & 2.4 & $1.8 \pm 0.0^{\mathrm{a}}$ & $95.0 \pm 0.8^{\mathrm{a}}$ & $0.26 \pm 0.10^{\mathrm{a}}$ \\
3.5 & 0.8 & $6.6 \pm 0.1^{\mathrm{A}^{* *}}$ & $95.0 \pm 0.3^{\mathrm{B}}$ & $0.41 \pm 0.10^{\mathrm{C}}$ \\
3.5 & 1.6 & $6.5 \pm 0.1^{\mathrm{A}}$ & $95.0 \pm 0.5^{\mathrm{B}}$ & $0.57 \pm 0.20^{\mathrm{C}}$ \\
3.5 & 2.4 & $6.7 \pm 0.3^{\mathrm{A}}$ & $95.0 \pm 0.3^{\mathrm{B}}$ & $0.38 \pm 0.10^{\mathrm{C}}$ \\
\hline
\end{tabular}

*Means followed by different letters, lowercase letters in the same column, differ statistically from each other by the Tukey test at $5 \%$ significance at $\mathrm{pH} 7.0(\mathrm{P}<0.05) .{ }^{* *}$ Means followed by different letters, capital letters in the same column, differ statistically from each other by the Tukey test at $5 \%$ significance at $\mathrm{pH} 3.5(\mathrm{P}<0.05)$. 
biopolymers exhibit negative charges, may occur via electrostatic interactions between positive fragments presented by proteins even in $\mathrm{pH}$ conditions above their IP (KAYITMAZER et al., 2013).

\section{Average size and size distribution and polydispersity} index

The average sizes of alginate microparticles with and without protein coating and an evaluation of the differences between their mean size and span index are presented in table 3. Notably, standard deviations are high for all the measurements due to the type of atomizer that is used. The use of a double fluid atomizer allows for a decrease in the average size of microparticles obtained by ionic gelation as compared to that obtained by formatting using syringes and needles of varied diameters. However, its design presents a high polydispersity in drop formation; consequently, it also presents a high polydispersity in the average sizes of the microparticles. Many parameters of the ionic gelation technique could interfere with the average size of microparticles such as the concentration and structure of polysaccharides, the diameter of the atomizer needle, and the distance of the needle to the calcium chloride solution (SMRDEL et al., 2008).

The statistical analysis shown significant and non significant differences when calcium level was increased (Table 3). As the standard deviation was very high because the use of the double fluid atomizer, it is difficult to clearly observe the effect of increase of calcium amount and the average size produced. The same effect was observed with respect to microparticles size with adsorbed protein compared with microparticles without protein. Although, the average size of microparticles increased with protein adsorption, significant and no significant differences were obtained. The treatment $2.4 \% \mathrm{Ca}^{2+}$ solution at
$\mathrm{pH} 3.5$ resulted in particles with a greater average diameter as compared to the other treatments.

Previous studies have reported similar sizes to those that are observed in this study using a double fluid atomizer and similar conditions. Alginate-pectin and alginate-egg protein microparticles produced by ionic gelation at $\mathrm{pH} 3.5$ had mean sizes of $261 \pm 19$ and $287 \pm 10 \mu \mathrm{m}$, respectively. Similarly, at $\mathrm{pH} 3.75$, uncoated and whey protein-coated microparticles of $259 \pm 22$ and $283 \pm 6 \mu \mathrm{m}$ have been observed (AGUILAR et al., 2015).

The polydispersity index (span index) (Table 3) were high and varied from 1.67 to 2.07 , 1.82 to 2.16 , and 1.72 to 2.16 for uncoated particles, coated particles at $\mathrm{pH} 3.5$, and coated particles at 7.0, respectively.

Morphology of the moist microparticles and morphological evaluation of protein adsorption using Coomassie blue

Morphologies of the microparticles produced in solutions with varying calcium concentrations (Figure 1), with and without protein coating at $\mathrm{pH} 3.5$ and 7.0 were visualized using Coomassie blue to identify if the protein was adsorbed (Figure 2) and optical microscopy. These images depicted that the microparticles obtained using different treatments were morphologically similar, with many microparticles possessing a spherical or an oval shape. The interiors of the particles were multinucleated, with the lipid material being homogeneously distributed throughout the microparticle's length. It was also possible to observe the presence of different microparticle sizes (large, medium, and small) in all the samples, corroborating the high standard deviations obtained in case of the mean particle size and span index. In addition to analyzing the external structure of microparticles,

Table 3 - Average size $\left(\mathrm{D}_{0.5} \mu \mathrm{m}\right)$ and (span index) of microparticles without and with proteins produced with different calcium concentration in solution and at different $\mathrm{pH}$ values.

\begin{tabular}{lccc}
\hline CaCl2(\%) & $\begin{array}{c}\text { Microparticles produced by ionic } \\
\text { gelation without protein (span index) }\end{array}$ & $\begin{array}{c}\text { Microparticles covered with protein at } \\
\text { pH 3.5 (span index) }\end{array}$ & $\begin{array}{c}\text { Microparticles covered with protein at } \\
\text { pH 7.0 (span index })\end{array}$ \\
\hline 0.8 & $154.7 \pm 63.4^{\mathrm{bA}}\left(1.85 \pm 0.04^{\mathrm{aB}}\right)$ & $258.2 \pm 82.9^{\mathrm{aB}}\left(1.82 \pm 0.08^{\mathrm{aB}}\right)$ & $197.4 \pm 107.5^{\mathrm{aA}}\left(1.72 \pm 0.13^{\mathrm{aA}}\right)$ \\
1.6 & $205.1 \pm 86.1^{\mathrm{aA}}\left(2.07 \pm 0.56^{\mathrm{aA}}\right)$ & $234.6 \pm 62.3^{\mathrm{aA}}\left(2.16 \pm 0.39^{\mathrm{bA}}\right)$ & $258.4 \pm 70.4^{\mathrm{bA}}\left(2.16 \pm 0.13^{\mathrm{bA}}\right)$ \\
2.4 & $204.8 \pm 41.1^{\mathrm{aA}}\left(1.67 \pm 0.07^{\mathrm{aA}}\right)$ & $334.6 \pm 23.1^{\mathrm{bB}}\left(1.86 \pm 0.07^{\mathrm{abB}}\right)$ & $239.9 \pm 33.4^{\mathrm{abC}}\left(1.78 \pm 0.13^{\mathrm{abAB}}\right)$ \\
\hline
\end{tabular}

Means followed by different letters, lower case letters in the same column and capital letters in the same row differ statistically from each other by the Tukey test at $5 \%$ significance $(\mathrm{P}<0.05)$. 


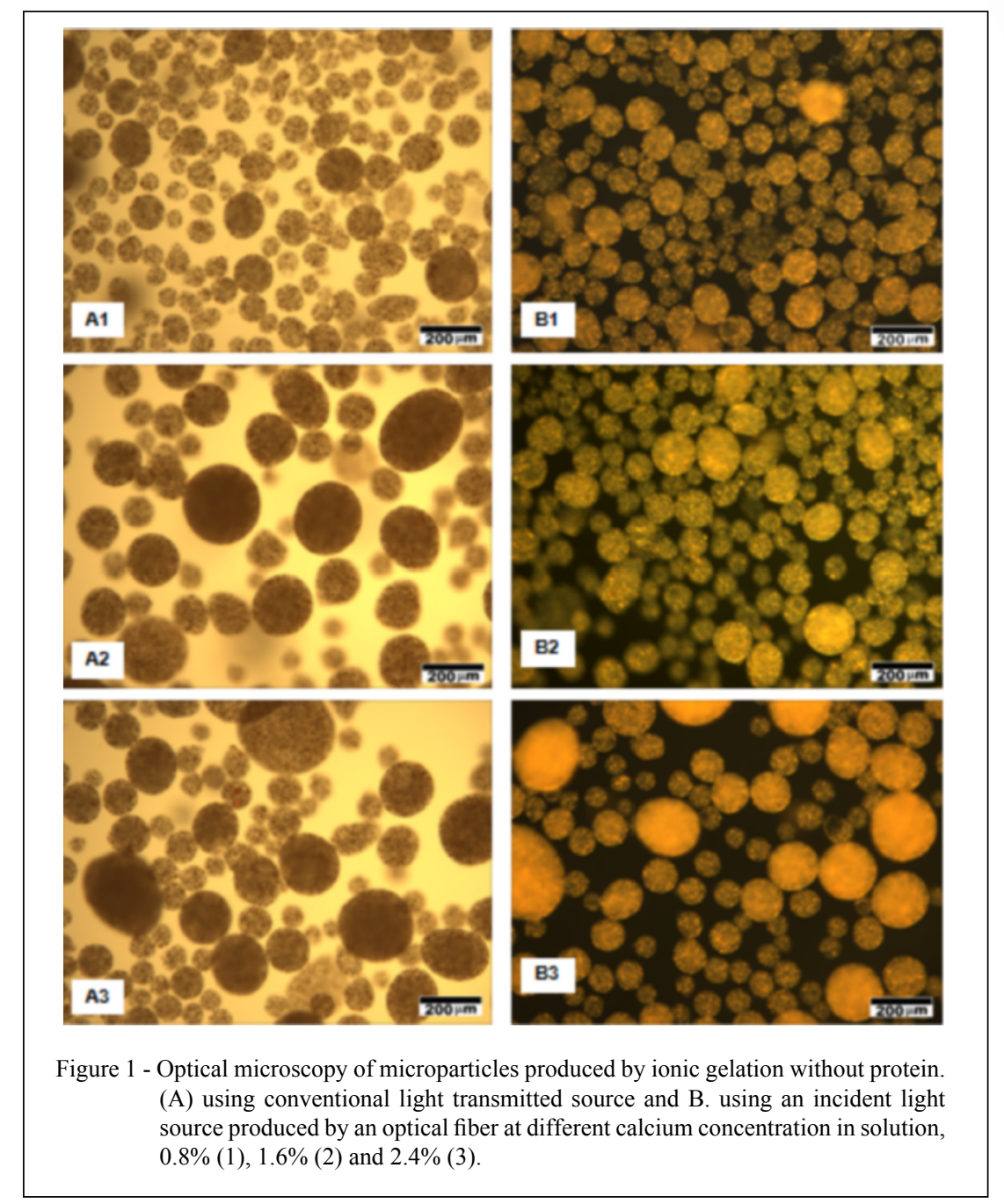

evaluation of the distribution of active materials encapsulated in their interior is important because this may influence functional characteristics such as permeability, integrity, microparticle digestibility, and active compound release (JONES \& MCCLEMENTS, 2010). Visually, the surfaces of all the microparticles were smooth with no porosity or apparent discontinuity. Hence, the protein adsorption (Figure 2) did not modify the characteristic sphericity of the particle.

The light microscopy results clearly demonstrated a significant improvement in the quality of the morphological observations while using the light generated by an optical fiber as compared to that observed while using the transmitted light generated by a conventional light source. This approach also allowed us to observe samples with a depth resolution similar to that achieved using scanning electron microscopy (SEM). However, unlike SEM, which requires sample dehydration and can, therefore, produce undesirable changes in microparticle morphology, which is followed by conductive coating prior to observation, our method can be performed using wet microparticles without any additional preparation using a conventional optical microscope.

Changes in microparticle morphology may occur as a function of the strength and intensity of electrostatic interactions between biopolymer solutions, which affects the microparticle swelling (JONES \&McCLEMENTS, 2010). In the present study, microparticles remained intact in all the assays, which are evident from their retained smooth 


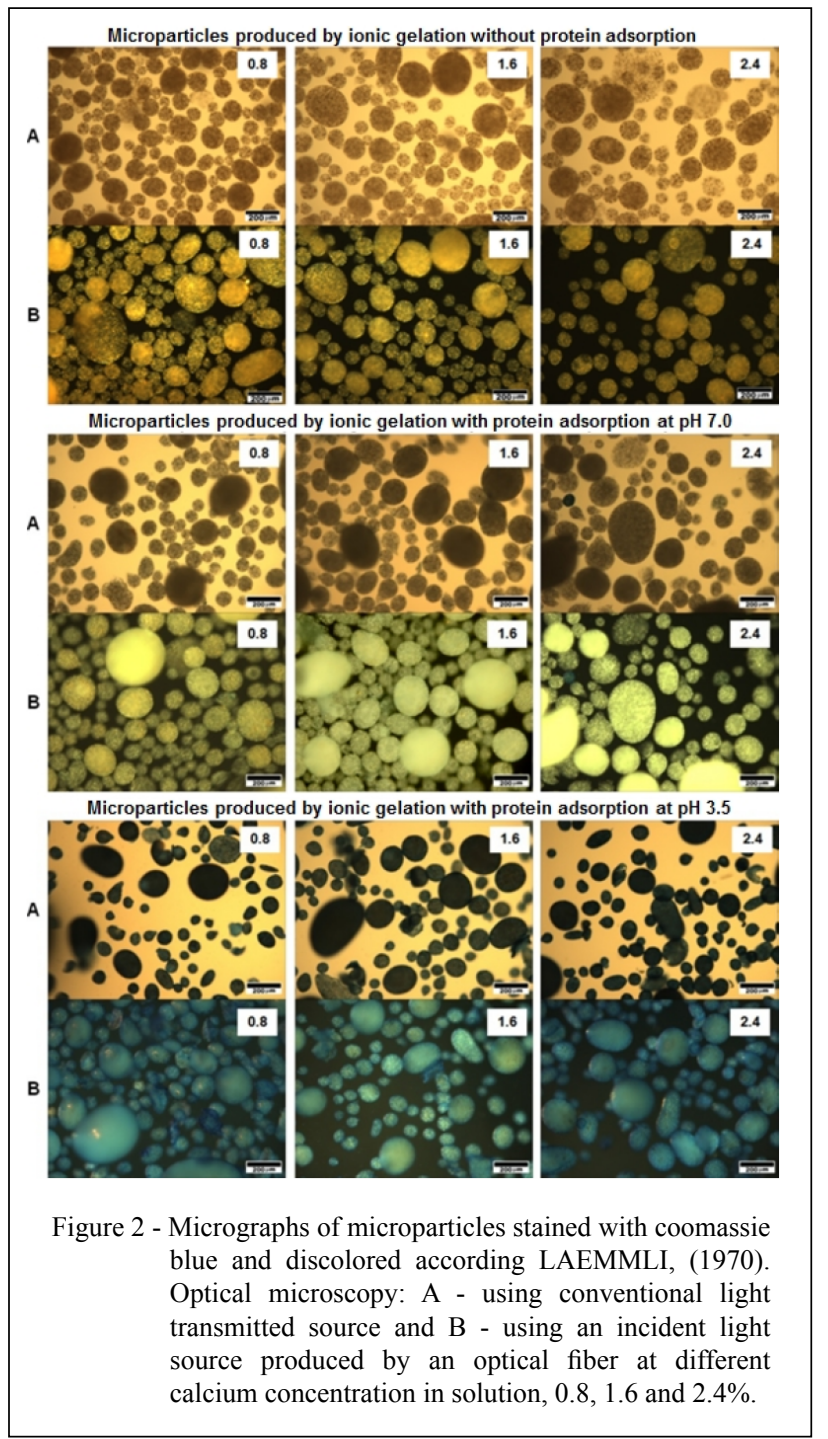

surfaces, even after incorporation of the soybean protein layer (Figure 2). Optical micrographs were similar to those presented by DOHERTY et al. (2012), who obtained microparticles with a continuous and visually smooth surface while producing alginate microcapsules with subsequent electrostatic deposition of a whey protein layer.

Protein adsorption onto microparticles, indicated by Coomassie Blue staining, can be clearly observed in figure 2 . Using conventional light microscopy, we observed uncoated microparticles with typical orange coloration after destaining due to paprika oleoresin. It is possible to observe the distribution of droplets in the emulsion due to the low opacity of particles (Figure 2 microparticles without protein adsorption, A). Protein coating at $\mathrm{pH} 7.0$ resulted in low protein adsorption, shown an increase of opacity making it difficult to observe the distribution of the encapsulated material (Figure 2 with protein adsorption at $\mathrm{pH} 7, \mathrm{~A}$ ). Protein coating at $\mathrm{pH} 3.5$ at which the highest protein adsorption was observed exhibited a marked increase of opacity and an more intense blue color on the surface of particles (Figure 2, protein adsortion at pH 3.5, A). These effects can also be observed at a higher resolution and with an increase in image depth when an optical fiber is used as the light source (Figure 2 without protein adsorption $\mathrm{B}$, with protein adsorption at $\mathrm{pH} 7.0 \mathrm{~B}$ and with protein adsorption at $\mathrm{pH} 3.5 \mathrm{~B}$ ).

Ciência Rural, v.48, n.12, 2018. 


\section{CONCLUSION}

Protein adsorption caused an increase in the mean microparticle size; however, without significant differences compared with microparticles without protein adsorption. Alginate microparticles and microparticles with adsorbed protein, showed a multinuclear distribution along the length of the microparticles. Microparticles coated with soy protein exhibited continuous and visually smooth walls. A high microparticle protein adsorption was observed at $\mathrm{pH} 3.5$ at which the microparticle produced by ionic gelation and protein exhibited opposite charges. This effect was minimized when the adsorption $\mathrm{pH}$ was 7.0 at which both the microparticles produced by ionic gelation and proteins exhibited negative charges, which prevented electrostatic interactions as a mechanism of protein adsorption. Concentrations of the calcium ions varied while producing the microparticles; however, an increase in the calcium ion concentration during ionic gelation had no effect on protein adsorption. The use of Coomassie staining for qualitative observations allowed us to quickly verify whether protein adsorption occurred. A fiber optic light source was used to detect a significant improvement in the quality of morphological observations, and it is possible to couple this method with several different types of optical microscopes.

\section{DECLARATION OF CONFLITING INTERESTS}

The authors declare no conflict of interest. The founding sponsors had no role in the design of the study; in the collection, analyses, or interpretation of data; in the writing of the manuscript, and in the decision to publish the results.

\section{ACKNOWLEDGMENTS}

The authors are grateful to FMC Biopolymers (Campinas, SP, Brazil) for the alginate PROTANAL RF 6650 and to Bremil (Arroio do Meio-RS, Brazil) for the soy protein concentrated.

\section{AUTHORS' CONTRIBUTIONS}

Gabriela Barros Silverio did the experiments and Izabela Dutra Alvim did the size measurements of the microparticles and the morphological evaluations. All authors contributed equally for the conception and writing of the manuscript. All authors critically revised the manuscript and approved of the final version.

\section{REFERENCES}

AGUILAR, K. C. et al. Protein adsorption onto alginate-pectin microparticles and films produced by ionic gelation. Journal of
Food Engineering, v. 154, p. 17-24, 2015. Available from: <http:// linkinghub.elsevier.com/retrieve/pii/S0260877414005494>. Accessed: Jul. 25, 2018. doi: 10.1016/j.jfoodeng.2014.12.020.

AOAC. Association of Official Analytical Chemists.Official methods of analysis. 18th Ed.,Maryland, MD, USA, 2006.

BAJPAI, S.K.; TANKHIWALE, R. Preparation, characterization and preliminary calcium release study of floating sodium alginate/ dextran-based hydrogel beads: part I. Polymer International, v.57, p.57-65, 2008. doi: 10.1002/pi.2311.

BRASIL. Resolução RDC ANVISA/MS no 268, de 22 de setembro de 2005. Regulamento técnico para produtos proteicos de origem vegetal, 2005. Available from: $<$ http://pesquisa.in.gov.br/imprensa/jsp/visualiza/index. jsp? jornal $=1 \&$ pagina $=371 \&$ data $=23 / 09 / 2005>$. Accessed: Jul. $25,2018$.

BUREY, P. et al. Hydrocolloid gel particles: formation, characterization, and application. Critical Reviews in Food Science and Nutrition, v.48, n.5, p.361-377, 2008. Available from: <https://doi.org/10.1080/10408390701347801>. Accessed: Jul. 26, 2018. doi: 10.1080/10408390701347801.

CHAMPAGNE, C. P.; FUSTIER, P. Microencapsulation for the improved delivery of bioactive compounds into foods. Current Opinion in Biotechnology, v.18, n.2, p.184-190, 2007. Available from: <https://www.sciencedirect.com/science/ article/pii/S0958166907000328>. Accessed: Jul. 25, 2018. doi: 10.1016/j.copbio.2007.03.001.

DESAI, K. G. H.; PARK, J. H. Recent developments in microencapsulation of food ingredients. Drying Technology, v.23, n.7, p.1361-1394, 2005. Available from: $<$ https://doi.org/10.1081/ DRT-200063478>. Accessed: Jul. 25, 2018. doi: 10.1081/drt200063478 .

DOHERTY, S. B. et al. Development and characterisation of whey protein micro-beads as potential matrices for probiotic protection. Food Hydrocolloids, v. 25, n. 6, p. 1604-1617, 2011. Available from: $<$ https://www.sciencedirect.com/science/article/pii/ S0268005X1000295X>. Accessed: Jul. 25, 2018. doi: 10.1016/j. foodhyd.2010.12.012

DOHERTY, S. B. et al. Application of whey protein microbead coatings for enhanced strength and probiotic protection during fruit juice storage and gastric incubation. Journal of Microencapsulation, v.29, n.8, p.713-728, 2012. Available from: $<$ https://doi.org/10.3109/02652048.2011.638994>. Accessed: Jul. 25, 2018. doi: 10.3109/02652048.2011.638994.

DRAGET, K.I. et al. Alginates.In: STEPHEN, A.M., PHILLIPS, G.O., WILLIAMS, P.A. Food polysaccharides and their applications, Boca Raton, CRC Press, 2006. Chapter 9, p.289-334.

EMBRAPA. A soja no Brasil. 2004. Available from: $<$ http://www. cnpso.embrapa.br/producaosoja/SojanoBrasil.htm>. Accessed: Sep.14,2016.

FARRIS, S. et al. Development of polyion-complex hydrogels as an alternative approach for the production of bio-based polymers for food packaging applications: a review. Trends in Food Science \& Technology, v.20, n.8, p.316-332, 2009. Available from: $<$ https://www. sciencedirect.com/science/article/abs/pii/S0924224409001538>. Accessed: Jul. 25, 2018. doi: 10.1016/j.tifs.2009.04.003.

Ciência Rural, v.48, n.12, 2018. 
GOUIN, S. Microencapsulation: industrial appraisal of existing technologies and trends. Trends in Food Science \& Technology, v.15, n.7-8, p.330-347, 2004. Available from: <https://www sciencedirect.com/science/article/abs/pii/S0924224403002723>. Accessed: Jul. 25, 2018. doi: 10.1016/j.tifs.2003.10.005.

JAFARI, S. M. et al. Encapsulation efficiency of food flavours and oils during spray drying. Drying Technology, v.26, n.7, p.816-835, 2008. Available from: <https://doi.org/10.1080/07373930802135972>. Accessed: Jul. 26, 2018. doi: 10.1080/07373930802135972.

JONES, O. G.; McCLEMENTS, D. J. Functional biopolymer particles: design, fabrication, and applications. Comprehensive Reviews in Food Science and Food Safety, v.9, n.4, p.374-397, 2010. Available from: <https://doi.org/10. 1111/j.1541-4337.2010.00118.x>. Accessed: Jul. 26, 2018. doi: 10.1111/j.1541-4337.2010.00118.x.

KAYITMAZER, A. B. et al. Protein-polyelectrolyte interactions. Soft Matter, v.9, n.9, p.2553-2583, 2013. Available from: $<$ http:// dx.doi.org/10.1039/C2SM27002A > . Accessed: Jul. 26, 2018. doi: $10.1039 / \mathrm{c} 2 \mathrm{sm} 27002 \mathrm{a}$.

KELCO. Alginate products for scientific water control, San Diego: Kelco, 1987. 35p.

KRASAEKOOPT, W et al. Evaluation of encapsulation techniques of probiotics for yoghurt. International Dairy Journal, v.13, n.1, p.3-13, 2003. Available from: <https:/www.sciencedirect.com/ science/article/pii/S0958694602001553?via\%3Dihub>. Accessed: Jul. 26, 2018. doi: 10.1016/s0958-6946(02)00155-3.

LAEMMLI, U. K. Cleavage of structural proteins during the assembly of the head of bacteriophage T4. Nature, v.227, n.5259, p.680-685, 1970. Available from: <http://dx.doi.org/10.1038/227680a0>. Accessed: Jul. 26, 2018. doi: 10.1038/227680a0.

LIU, L. et al. Pectin in controlled drug delivery - a review. Cellulose, v.14, n.1, p.15-24, 2007. Available from: <https://doi org/10.1007/s10570-006-9095-7>. Accessed: Jul. 26, 2018. doi: $10.1007 / \mathrm{s} 10570-006-9095-7$.

MAESTRELLI, F. et al. Development of enteric-coated calcium pectinate microspheres intended for colonic drug delivery. European Journal of Pharmaceutics and Biopharmaceutics, v.69, n.2, p.508-518, 2008. Available from: <https://www. sciencedirect.com/science/article/abs/pii/S0939641107004055>. Accessed: Jul. 26, 2018. doi: 10.1016/j.ejpb.2007.12.004.

MESTDAGH, M.M; AXELOS, M.S.V. Physico-chemical properties of polycarboxylate gel phase and their incidence on the retention/release of solutes. Biopolymer Science: Food and Nonfood Applications, Montpellier, p.303-314, 1998.

MOLINA-ORTIZ et al. Relationship between structural changes and functional properties of soy protein isolates-carrageenan systems. Food Hydrocolloids, v.18, n.6, p.1045-1053, 2004. Available from: <https:/www.sciencedirect.com/science/article/ pii/S0268005X04000505>. Accessed: Jul. 26, 2018. doi: 10.1016/j. foodhyd.2004.04.011.

MUKAI-CORREA, R. et al. Controlled release of protein from hydrocolloid gel microbeads before and after drying. Current Drug Delivery, v.1, n.3, p.265-273, 2004. Available from: <http:// www.eurekaselect.com/node/62733/article>. Accessed: Jul. 25, 2018. doi: 10.2174/1567201043334803.
PATHAK, T. S. et al. Effect of calcium ion (cross-linker) concentration on porosity, surface morphology and thermal behavior of calcium alginates prepared from algae (Undaria pinnatifida). Carbohydrate Polymers, v.81, n.3, p.633-639, 2010. Available from: <http://www.sciencedirect.com/science/ article/pii/S0144861710001943>. Accessed: Jul. 27, 2018. doi: 10.1016/j.carbpol.2010.03.025.

$\mathrm{ROACH}, \mathrm{P}$ et al. Interpretation of protein adsorption: surfaceinduced conformational changes. Journal of the American Chemical Society, v.127, n.22, p.8168-8173, 2005. Available from: <https://doi.org/10.1021/ja042898o >. Accessed: Jul. 27, 2018. doi: $10.1021 / \mathrm{ja} 042898$ o.

SANTIAGO, L. G. et al. Adsorption of soy protein isolate at air-water and oil-water interfaces. Colloids and Surfaces A: Physicochemical and Engineering Aspects, v.323, n.1-3, p.155162, 2008. Available from: <https://www.sciencedirect.com/ science/article/pii/S0927775707009648> . Accessed: Jul. 26, 2018. doi: 10.1016/j.colsurfa.2007.11.001.

SCHOUBBEN, A. et al. Development of a scalable procedure for fine calcium alginate particle preparation. Chemical Engineering Journal, v.160, n.1, p.363-369, 2010. Available from: <https:// www.sciencedirect.com/science/article/pii/S1385894710002068>. Accessed: Jul. 26, 2018. doi: 10.1016/j.cej.2010.02.062.

SGARBIERI, V. C. Proteínas em alimentos proteicos: propriedades, degradações, modificações. São Paulo: Varela, 517 p., 1996.

SMRDEL, P. et al. The influence of selected parameters on the size and shape of alginate beads prepared by ionotropic gelation. Scientia Pharmaceutica, v.76, n.1, p.77-89, 2008. doi: 10.3797/ scipharm.0611-07.

SRIAMORNSAK, P.; KENNEDY, R. A. Swelling and diffusion studies of calcium polysaccharide gels intended for film coating. International Journal of Pharmaceutics, v.358, n.1-2, p.205213, 2008. Available from: <https://www.sciencedirect.com/ science/article/pii/S0378517308002093>. Accessed: Jul. 26, 2018. doi: 10.1016/j.ijpharm.2008.03.009.

TELLO, F. et al. Alginate and pectin-based particles coated with globular proteins: production, characterization and antioxidative properties. Food Hydrocolloids, v.43, p.670-678, 2015. Available from: <https://www.sciencedirect.com/science/ article/pii/S0268005X14002720>. Accessed: Jul. 26, 2018. doi: 10.1016/j.foodhyd.2014.07.029.

VELASQUEZ, M. T.; BHATHENA, S. J. Role of dietary soy protein in obesity. International Journal of Medical Sciences, v.4, n.2, p.72-82, 2007. Available from: <http:// www.ncbi.nlm.nih.gov/pubmed/17396158>. Accessed: Jul. 26,2018 .

WANDREY, C. et al. Materials for encapsulation. In: ZUIDAN, N.J., NEDOVIC, V.A. Encapsulation technologies for active food ingredients and food processing. New York: Springer, 2010. Chapter 3, p31-100. Available from: <http://link.springer. com/10.1007/978-1-4419-1008-0>. Accessed: Jul. 26, 2018. doi: 10.1007/978-1-4419-1008-0.

YEUNG, T. W. et al. Microencapsulation in alginate and chitosan microgels to enhance viability of Bifidobacterium longum for oral delivery. Frontiers in Microbiology, v.7, p.494, 
Production and characterization of alginate microparticles obtained by ionic gelation and electrostatic adsorption of concentrated soy... 12

2016. Available from: <http://www.ncbi.nlm.nih.gov/pmc/ articles/PMC4835488/>. Accessed: Jul. 26, 2018. doi: 10.3389/ fmicb.2016.00494.

ZEEB, B. et al. Retention and release of oil-in-water emulsions from filled hydrogel beads composed of calcium alginate: impact of emulsifier type and pH. Soft Matter, v.11, n.11, p.2228-2236, 2015. Available from: <http://dx.doi.org/10.1039/
C4SM02791D>. Accessed: Jul. 26, 2018. doi: 10.1039/ c4sm02791d.

ZHANG, Z. et al. Protein encapsulation in alginate hydrogel beads: Effect of $\mathrm{pH}$ on microgel stability, protein retention and protein release. Food Hydrocolloids, v.58, p.308-315, 2016. Available from: <http:// www.sciencedirect.com/science/article/pii/S0268005X16300935>. Accessed: Jul. 26, 2018. doi: 10.1016/j.foodhyd.2016.03.015. 